補緅誌, J Jpn Prosthodont Soc, 32:1100 1109, 1988.

原著論文

$$
\text { ポーセレンラミネートクラウンの力学的検討 }
$$

日永田裕子冲本 公繪家入 浩二平安 亮造

\title{
Stress Analysis of Porcelain Laminate Veneers
}

\author{
Hiroko Hieda, Kimie Okimoto, Kōzi Ieiri and Ryōzō Hirayasu
}

\begin{abstract}
For this purpose, the stress distribution produced on the porcelain and resin cement layer of prosthetic porcelain laminate veneer crown on upper central incisor, under the different loads were applied to the normal coverage portion and the incisal edge portion at an angle of $45^{\circ}$ or $0^{\circ}$ to the tooth axis, were estimated in the present study with respect to the shape of the abutment tooth for the laminate veneer crown, by means of finite element method as well as model tests.
\end{abstract}

The results obtained were as follows :

1. When the load force was applied to the incisal edge of abutment tooth covered over the incisal edge by porcelain, the tensile stress in the porcelain and the maximum shear stress at resin cement layer were most distinct.

Furthermore load distribution was parrarel to the tooth axis, the highest tensile stress was produced in the porcelain.

2. The maximum shear stress at resin cement layer were dependented on the sites of the prosities in resin cement layer rather than the amount of them.

3. As for a model test, there was no risk of fracture of the porcelain under the load within $15 \mathrm{~kg}$.

Key words : stress analysis, finite element method, porcelain laminate veneers

\section{I. 緒 言}

変色歯, 失活歯, う蝕や破折による歯質の実質欠損, 苗間離開などの前歯の審美回復には，従来よりレジンお よびポーセレンジャケットクラウン, 陶材焼付冠修復法 などが用いられ，近年ではセラモメタル他セレストアク ラウン等が普及しつつある.

九州大学歯学部歯科補緅学第一辚座 (主任 : 平安亮造教授) 1 st Department of Prosthetic Dentistry Faculty of Den. tistry, Kyushu University (Chief : Prof. Ryōzō Hirayasu) 昭和 63 年 4 月 4 日受付
近年, 欧米を中心に臨床に定着しつつあるポーセレン ラミネートベニア法 ${ }^{121)}$ は，歯質の削除量が少ないとい う最大限の利点に加えて色調再現む優れており, さらに 強度的にも光重合コンポジット・レジンをポーセレンベ ニアと歯質との間に介在させて接着するため, ベニアと 歯翼が一体化し，さらにシランカップリングの併用によ り強度が増す22 25) という点からこれから先多く臨床に とり入れられていくと思われる.

多数歯の歯冠修復む，フルカバレッジに比較するとラ ミネートクラウンは臨床術式も簡便に行えるという利点 をもっているが, 反面, 破折に対する危惧, 支台歯の形 態 ${ }^{26)}$, 適応症の選択といった問題をかかえている. 


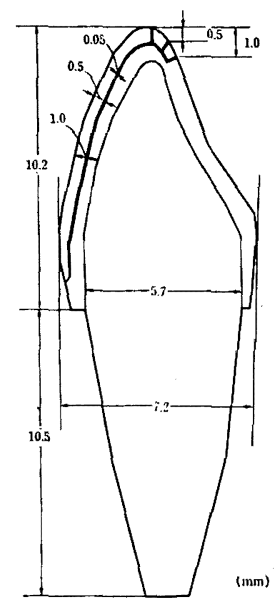

Fig. 1 モデル外形と寸法

今回は，ポーセレンラミネートベニア法を施した上顎 中切歯に咬合力が加わった場合を想定して, 支台歯の形 態の違いおよび荷重位置の差, さらにラミネートベニア を支台歯に合着する際にレジンセメント層に発生する気 泡の存在が修復物に及ぼす力学的な影響を明らかにする ために, 二次元有限要素法による解析と模型実験を行っ た.

\section{II. 解析方法}

\section{1. 有限要素法による解析}

本研究に用いたモデル外形と寸法の決定に際しては, 中切歯抜去歯牙 50 本中より平均的な形態と寸法をもつ 歯牙を万能投影器でトレースを行った。

さらに歯牙を正中矢状面で切断し，エナメル層の厚さ を測定したものと，成書 ${ }^{27 ~ 31) ~}$ 矢状断面のエナメル層の厚さ等を求めた.

支台歯の唇側歯質削除量は $0.5 \mathrm{~mm}$ とし, 歯頸部辺縁 形態はシャンファータイプを想定した (Fig. 1).

Fig. 2 は有限要素法による解析のためのモデルの分割 図である. 節点数 763 , 要素数 $740 \mathrm{~K}$ 分割し, 固定点 (歯根部) 27 カ所とした.

Fig. 3 は支台歯, ラミネート修復物形状と荷重位置で ある. 支台歯形態は, 支台歯の切縁形態が切端までで, 修復物が切縁をお㧍わないものを Type I, 切縁を 0.5 $\mathrm{mm}$ 削除し修復物が舌側 $0.5 \mathrm{~mm}$ まで被覆する場合を Type II，さらに修復物が舌側の $1.0 \mathrm{~mm}$ まで被覆する ものを Type III の 3 type とした.

荷重位置は, 切端 (A), 切緣より $1.0 \mathrm{~mm}$ 歯頸部寄り

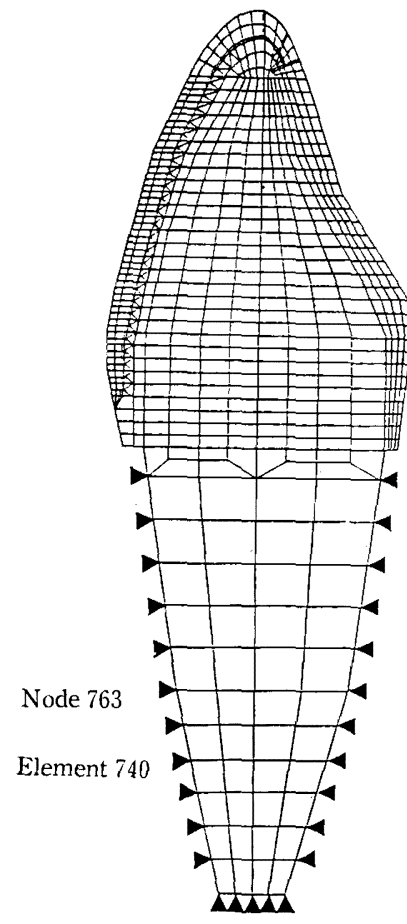

Fig. 2 分割図

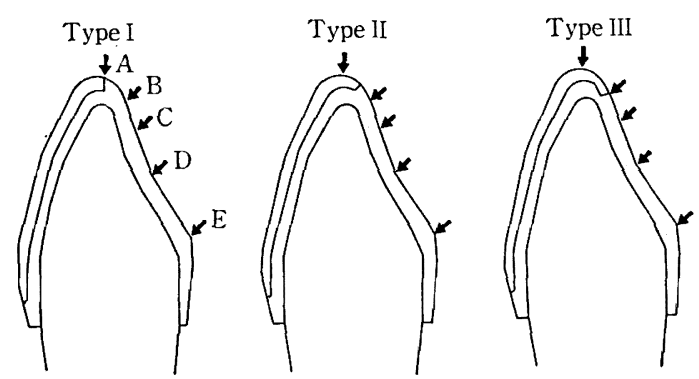

Fig. 3 モデル外形と荷重位置

(B)，平均的被蓋位置 (C), 舌面中央 (D)，基底結節部 （E）の 5 力所に定め, 荷重方向は (A) のみ歯軸と平行 $\left(90^{\circ}\right)$ にし，(B) (C) (D)（E) は歯冠部画軸に対して $45^{\circ}$ の方向とした．また，荷重量は前菌の最大咬合力の $15.0 \mathrm{~kg}$ （解析值は $22.5 \mathrm{~kg}$ ）を想定した.

Table 1 は今回使用した各構成材料の材料定数である. 以上， 5 種類の荷重条件， 3 種類のモデル形状の組合 せにより, 15 種類の解析に加え, 修復物を支台㐘に接着 する際に生じるセメント層の気泡を想定して 9 種類の気 泡発生時の条件設定 (Fig. 10) により, 計 24 種の解析 を富士通 FEM IV にて行った。

解析結果の評価には，ポーセレンベニアクラウン部は 


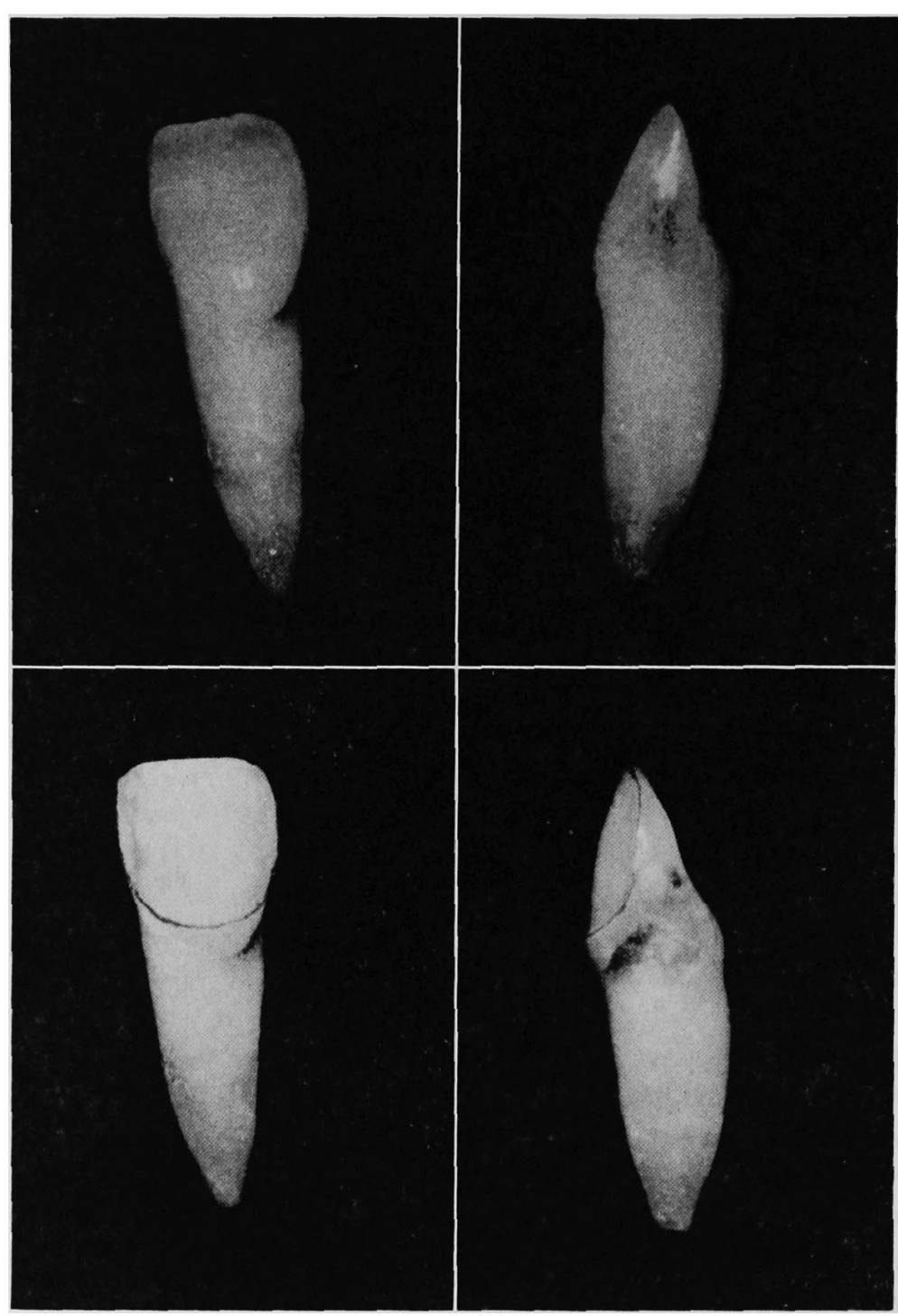

Fig. 4 模型実験

Table 1 材料定数

\begin{tabular}{l|c|c}
\hline \hline & $\begin{array}{c}\text { Young's Modulus } \\
\left(\mathrm{kg} / \mathrm{mm}^{2}\right)\end{array}$ & Poisson's Ratio \\
\hline Enamel & 6000.0 & 0.30 \\
Dentin & 1400.0 & 0.28 \\
Porcelain & 10000.0 & 0.20 \\
Resin & 300.0 & 0.35 \\
\hline
\end{tabular}

最大引張応力, レジンセメント部では剪断応力を応力評 価とした.
2. 模型実験 - 材料と方法

比較的形態の似た上影中切歯抜去歯牙 20 本を用い,13 本を FEM (Finite Element Method) モデルでの Type I (切端まで), 7 本を Type III (舌側 $1.0 \mathrm{~mm}$ まで被覆) の支台歯形成を行った. 歯頸部マージンはシャンファー type, 歯質削除量は $0.5 \mathrm{~mm}$ とし, 隣接面は接触点より わずかに唇面寄りまで削除した (Fig. 4).

ラミネートクラウンの焼成には, 米 Pentron 社ペン クラフトポーセレンパウダーを用い, $100^{\circ} \mathrm{C} て ゙ 30$ 分乾 燥, $600^{\circ} \mathrm{C}$ で 15 分間予備乾燥後, $900^{\circ} \mathrm{C}$ で 5 分間第一次 焼成を行った. 第二次焼成（第一次と同じ）後, 大気中 


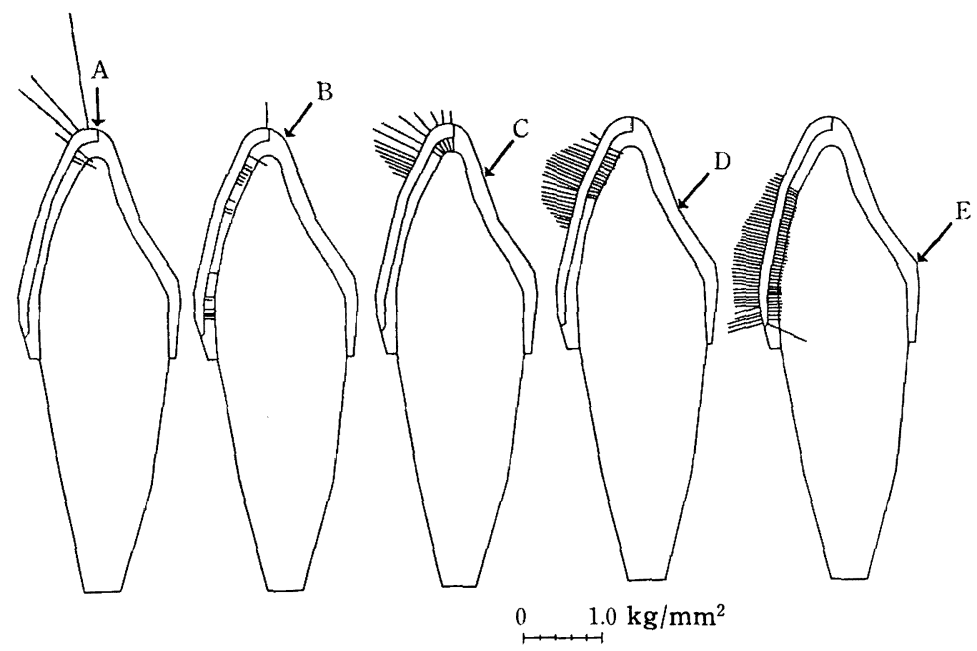

Fig. 5 ポーセレンベニアに生じる最大主応力

にてグレーズを行った ${ }^{17,19,21)}$.

焼成を終えたベニアクラウンの平均厚さは切端 0.738 $\mathrm{mm}$, 中央部 $0.654 \mathrm{~mm}$, 歯頸部 $0.589 \mathrm{~mm}$ であった.

これらのラミネートベニア内面をサンドブラスティン グ，超音波洗浄 ( 3 分間) 後, エッチング ( $2 \mathrm{~N}$ 塩酸溶 液, 15 分間), 水洗, ボンディング剤塗布 (30 秒), 乾燥 処理をした. また，エナメル質をエッチング (1 分間) 後, 水洗, 乾燥, ボンディング剤塗布 (30秒), 乾燥後, 上記ラミネートクラウンを光重合レジン（日 機 装, “レ インボー”システム)にて 30 秒間照射重合した.

荷重試験は, 各モデル荷重方向が舌面に垂直になるよ うにして超硬石こうで固定し, 荷重位㯰は切端と正常被 蓋位置に相当する切端から $2.8 \mathrm{~mm}$ の 2 力所とした.

島津オートグラフ S 型を使用し, 線状の静止圧荷重を クロスヘッドスピード $0.5 \mathrm{~mm} / \mathrm{min}$ で加え, ベニアクラ ウンが剝離あるいは破折した時の荷重值を測定した。

\section{III. 結 果}

\section{1. 有限要素法の結果}

1）ポーセレンベニアに生じる最大主応力

Fig. 5 は Type I に A, B, C, D, E の各荷重を加えた 場合に，ポーセレンベニア部分に生じる $0.1 \mathrm{~kg} / \mathrm{mm}^{2}$ 以 上の最大主応力の大きさを図示したものである.内外二 層に分けたポーセレン部の外側要素に生じる応力值は外 に向かって, 内側に生じる応力は内に向かって表してい る.

$\mathrm{A}$ 荷重では, 引張り応力は切端部分に極端に集中して

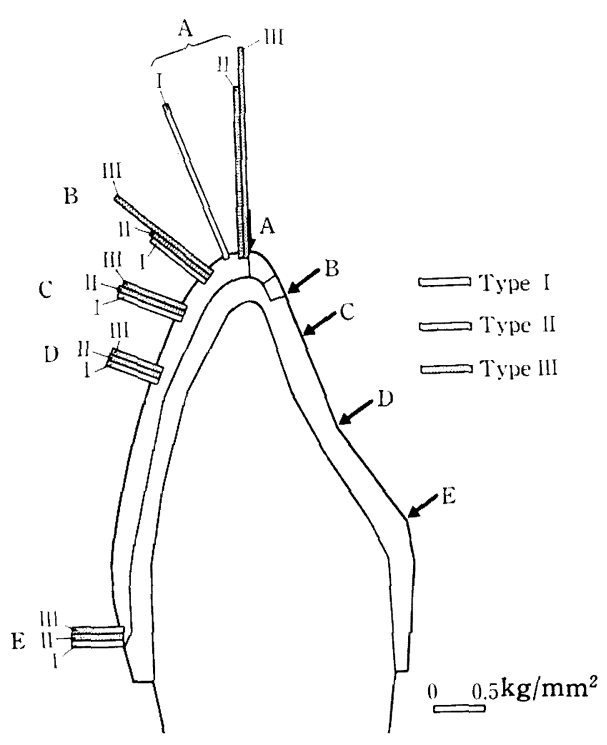

Fig. 6 各 type, 各荷重においてポーセレンベニア 部に生じる引張り応力の最大值とその位圆

いる. B 荷重では, 歯頸部近くと支台歯の切端高に相当 する部位に比較的均等な大きさで応力が分布する. C 荷 重では切端から支台歯の切断高にかけて，D荷重では支 台歯の $1 / 3$ の高さをピークとして応力が分布している.

$\mathrm{E}$ 荷重では切端寄り $1 / 3$ を除くポーセレン部分に応力が 発生し，歯頸部が最も大きな値となっている．また，応 カの最大值は, $\mathrm{A}$ 荷重での切端付近の $1.48 \mathrm{~kg} / \mathrm{mm}^{2}$ で あった。

Fig. 6 は, 各 type, 各荷重においてポーセレンベニア 


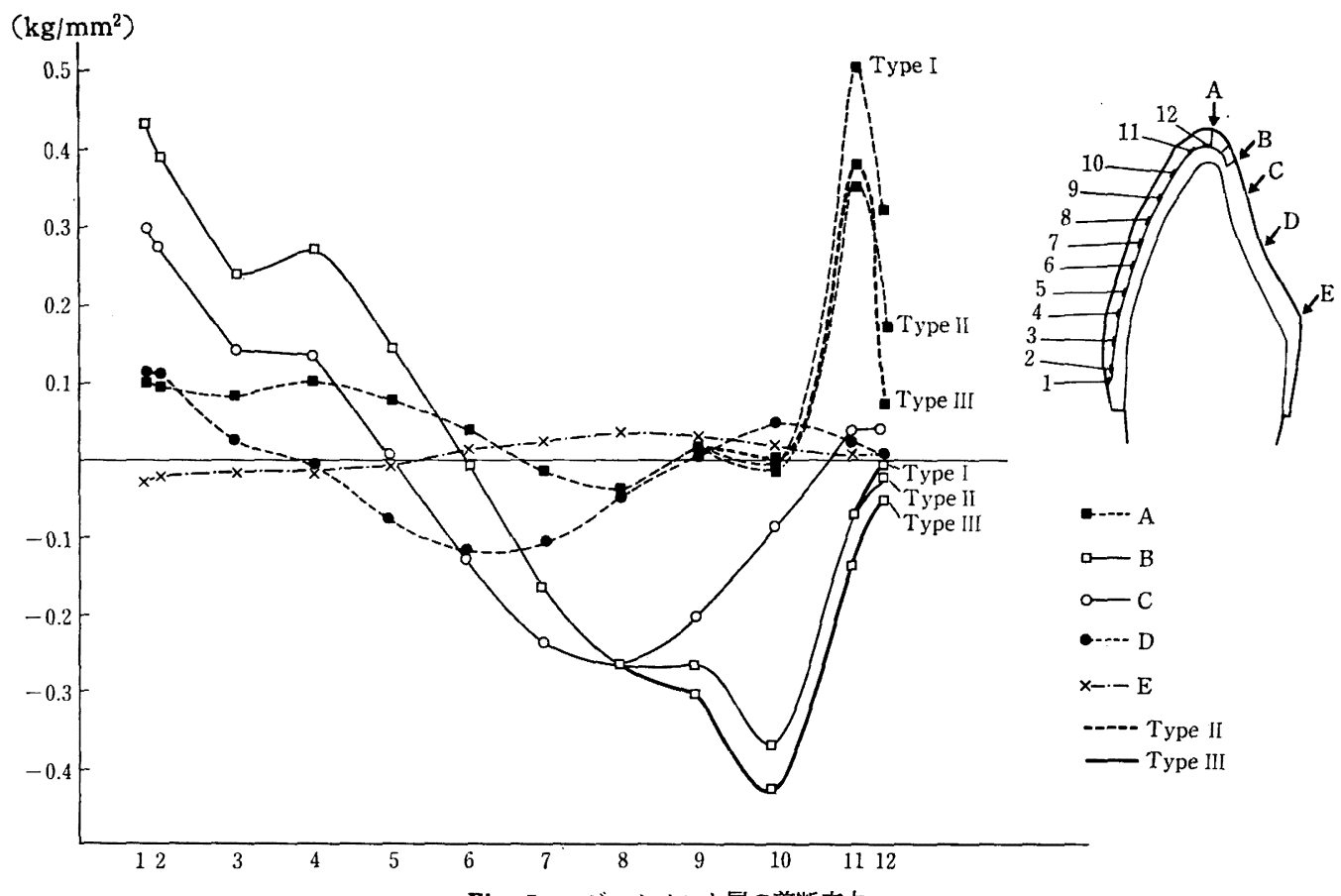

Fig. 7 レジンセメント層の剪断応力

部に生じる引張り応力の最大值とその位置の比較をした ものである.

荷重 A, B では Type による顕著な差が認められた. 荷重 A では, 切端付近に発生した最大忘力値は Type III は Type I の約 1.32 倍, Type II の約 1.29 倍を示しそ の值は $2.097 \mathrm{~kg} / \mathrm{mm}^{2}$ であった. また, 荷重 Bでも, Type III が一番応力值が大きく $1.16 \mathrm{~kg} / \mathrm{mm}^{2}$ で Type I, Type II の約 1.66 倍の値を示した. 荷重位置 C, D, E では最大応力発生位置, 大きさとも Type 別による差は 認められなかった.

2) レジンセメント層の剪断応力

Fig. 7 は Type I〜III の各 Type に荷重 A〜E を加え た場合のレジンセメント層の剪断応力の比較である.レ ジンセメント層を(Fig. 7 の右側) のように，歯頸部か ら 1〜12 に区分して，各要素の剪断応力を䅠軸に，部位 を横軸にプロットした.

A, B 荷重では 1〜7までは荷重による差はないが，部 位 8,10 から差が認められた. A 荷重では部位 11 で Type I の剪断応力値が一番大きくなり, Type III, Type II と続き, 部位 12 で逆転している. B 荷重では部 位 8 まで Type による差はないが，それ以後は Type III の剪断応力值が最大で, Type I，II にはほとんど差は認 められなかった. C, D, E 荷重については, Type による
剪断応力値の差は認められなかった. 次に荷重位圆別に 見ると, D, E 荷重では全体に剪断応力は顕著ではなく， 最大で $0.042 \mathrm{~kg} / \mathrm{mm}^{2}$ が部位 10 に生じているのに対し， $\mathrm{A}$ 荷重では部位 $11, \mathrm{~B}$ 荷重では部位 1 と部位 10 の剪断 応力值が著しく大きく, その値は $0.4 \sim 0.5 \mathrm{~kg} / \mathrm{mm}^{2}$ で あった.

Fig. 8 は, Type $1 〜 \mathrm{III}$ のモデルに A〜E の荷重を加え た時に各ベニア先端部（切端部および歯頸部）に発生す る剪断応力を比較したものである. Type I〜 III の歯頸 部を a, Type I の切端部を b, Type II の切端部を c, Type III の切端部を d としている.

歯頸部aでは，各 Type による差は認められず, 荷重 別に見るとB荷重で剪断応力は最大となり $0.43 \mathrm{~kg} / \mathrm{mm}^{2}$ であった. 切端部を見ると, Type I での切端部 b では A 荷重で最大 $0.32 \mathrm{~kg} / \mathrm{mm}^{2}$ であるが, Type II の先端部 c ではA荷重で Type I (b) の約 7 倍の $2.25 \mathrm{~kg} / \mathrm{mm}^{2}, \mathrm{~B}$ 荷重で $0.94 \mathrm{~kg} / \mathrm{mm}^{2}$ と剪断応力值は増大している. Type III の先端部 d では, Type II の先端部 cよりはや や小さいながらもA荷重で Type I (b) の約 1.65 倍の $0.53 \mathrm{~kg} / \mathrm{mm}^{2}$, B 荷重で最大剪断応力值 $1.04 \mathrm{~kg} / \mathrm{mm}^{2}$ を 示している.

3) 有気泡時の剪断応力

ラミネートクラウンを支台歯に装着する際にレジンセ 


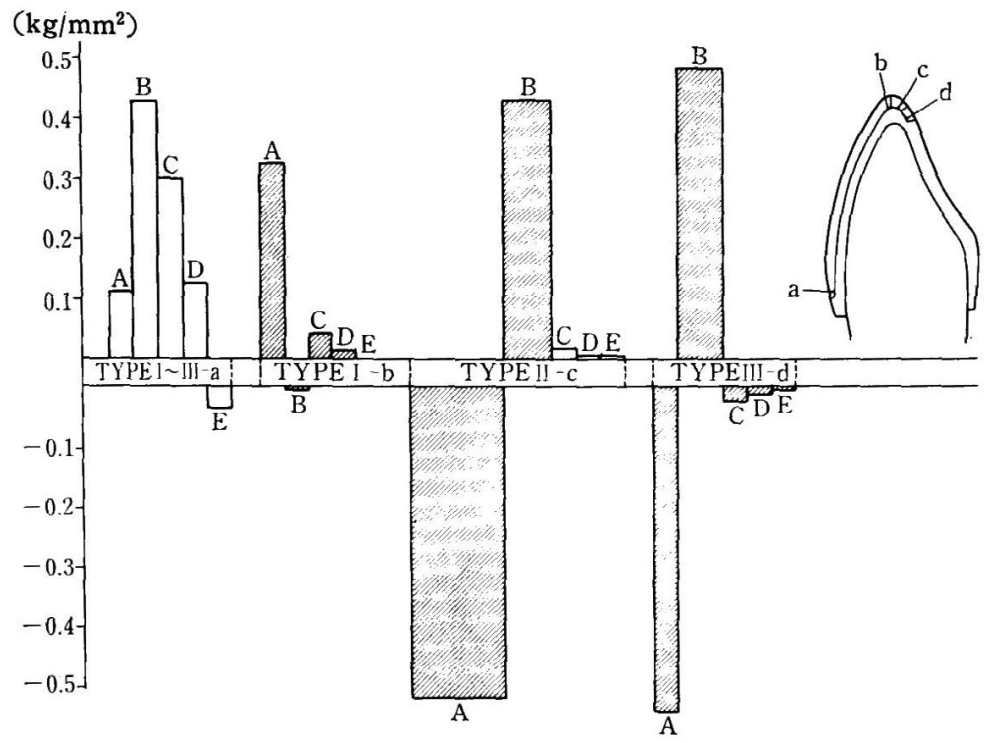

Fig. 8 ベニア先端部に生しる剪断応力

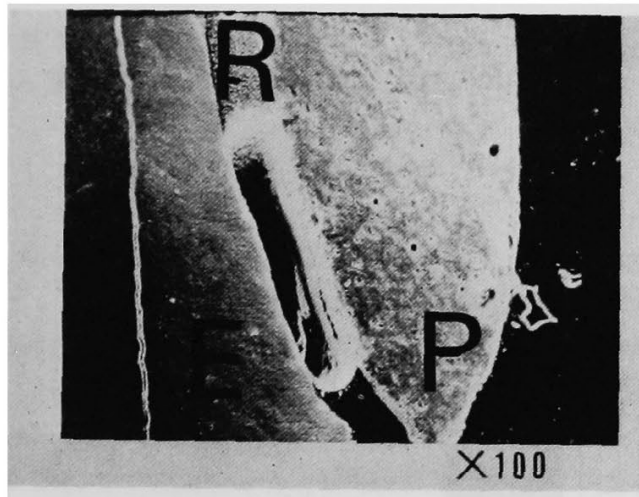

(A)

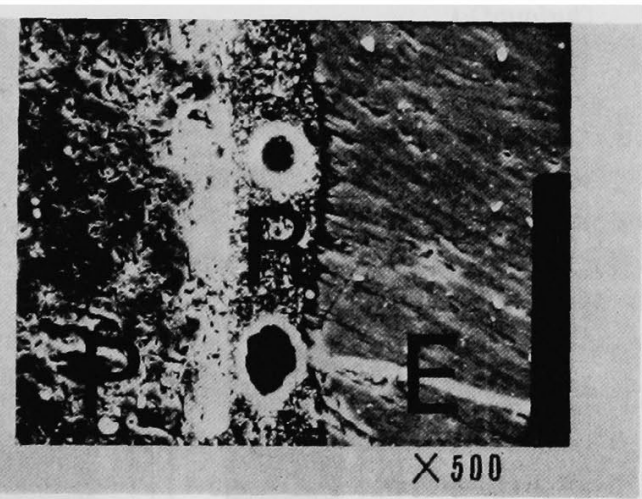

(B)

Fig. 9 レジン層の電顕写真

（A）集中気泡 (B) 分散気泡

メント層に発生する気泡には, 電䫓写真 (Fig. 9) のよ うに分散気泡と集中気泡がみられる.

したがって, Fig. 10 のように気泡を分散気泡と集中 気泡に分けて有気泡時の解析モデルを設定した。

モデルは Type I とし, 荷重位置は c (平均的被蓋位 置) で行った. a , b c c は分散気泡でレジンセメント層面 積の各 $6.7,10,15 \%$ 気泡が存在するものである. $\mathrm{d}, \mathrm{e}, \mathrm{f}$, g, h, i は集中気泡で, d は歯頸部寄り $5 \%$ の気泡が 2 個， 計 $10 \%$ の気泡の存在を示し, 以下同様に, e は歯頸部に $5 \%$ の気泡が 1 個と歯冠中央に $5 \%$ の気泡が 1 個 計 10 $\%, \mathrm{f}$ は切端寄りに $5 \%$ の気泡が 1 個，g は歯頸部に $5 \%$ の気泡が 1 個， $\mathrm{h}$ は歯冠中央よりやや歯頸部寄りに $5 \%$
の気泡が 1 個, i は切端に $5 \%$ の気泡が 1 個である.

結果は, Fig. 11 に示寸. 応力比較部位はレジンセメン ト層の 1 : 歯頸部マージン部, 2: マージンのやや上方, 3: ラミネートクラウンのほぼ中央, 4 : 切端マージン部 の剪断応力とした．なお横軸は各気泡のケース, 緃軸は 盖断応力值を示している.

部位 1 （歯頸部マージン部）における盖断応力をみる と, 分散気泡 ( $\mathrm{a}, \mathrm{b}, \mathrm{c}$ ) では気泡がない場合 (control) よりわずかに剪断応力は上㫒している.この時の control の応力值は $0.295 \mathrm{~kg} / \mathrm{mm}^{2}$ であった. 集中気泡 (d〜 i）では, 切端付近に気泡が存在する $f, i$ 以外は d, e, g, h ともに剪断応力値は約 $20 \%$ 増加している. 


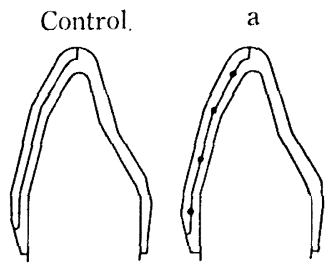

$6.7^{\prime \prime} \circ$

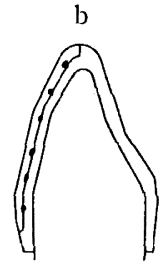

$10^{\circ} \%$

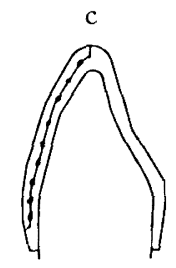

$15 \%$

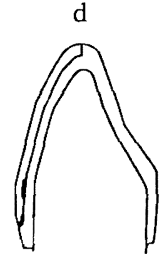

$10 ? \%$

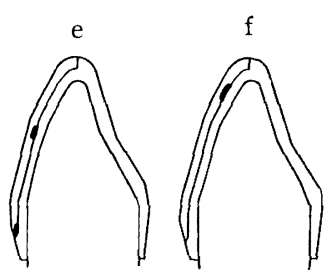

$10 \%$

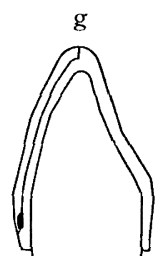

$5 \%$

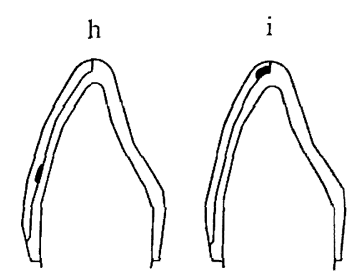

$5 \%$
$5 \%$

Fig. 10 気泡の設定

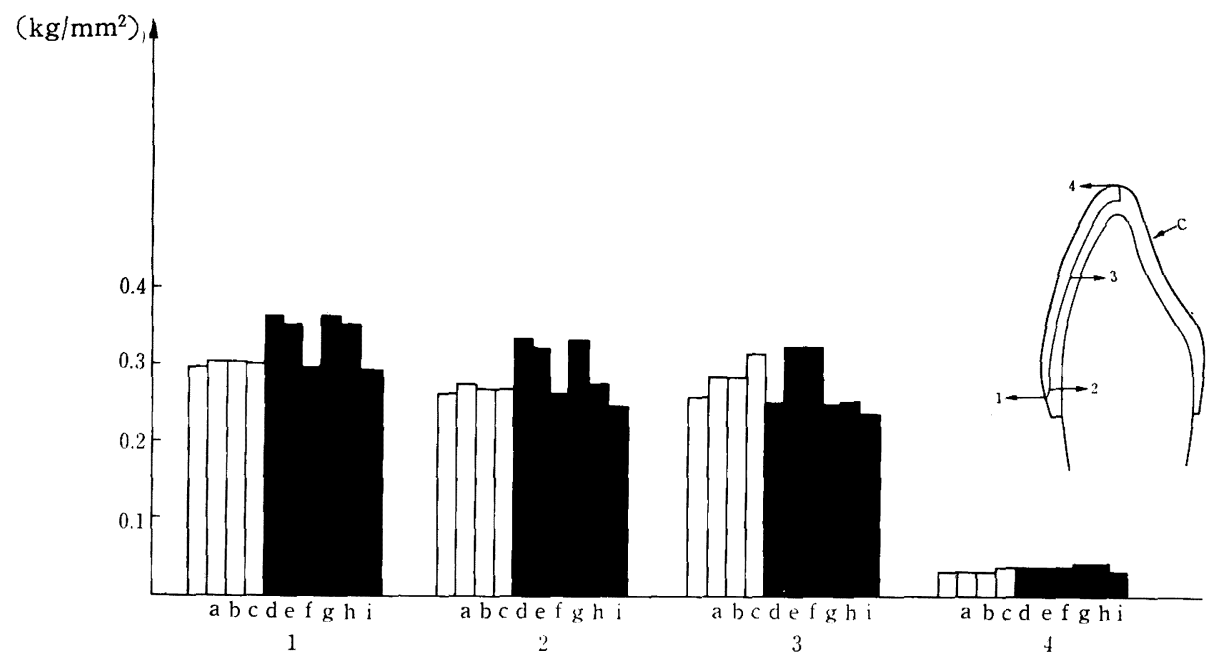

Fig. 11 レジンセメント層の剪断応力（気泡発生時）

部位 2 でも部位 1 とほぼ同傾向にあるが，歯頸部に集 中気泡が存在する $\mathrm{d}, \mathrm{e}, \mathrm{g}$ の剪断応力が約 $25 \%$ 上舁し ている.

部位 3 では, 部位 1, 2 で control と差が生じなかっ た分散気泡でも剪断応力は上昇し，気泡 率が $15 \%$ にな ると, control に比べ約 $20 \%$ 応力值が大きくなっている. 集中気泡では，気泡の位置が測定部位に近い e, f の值が 約 $25 \%$ 大きくなっている.

部位 4 では，気泡の位置，気泡の量にかかわらず $\mathrm{a} \sim \mathrm{i}$ ともに剪断応力值は control と差はなく, 值は $0.03 \mathrm{~kg} /$ $\mathrm{mm}^{2}$ 以下であった.

\section{2. 模型実験結果}

ポーセレンベニアクラウンの破折テスト結果を Fig. 12 に示す.

Type I で, ベニアクラウンの剝離が 7 ケース $(22,33$, $52,55,57,58,130 \mathrm{~kg}$ ), ベニアクラウンの破折が 4 ケー ス $(22,28,57,63 \mathrm{~kg})$ ，歯質の破折が 2 ケース $(75,82$ kg) であった.

Type III では, ベニアクラウンの剝離が 2 ケース（52， 


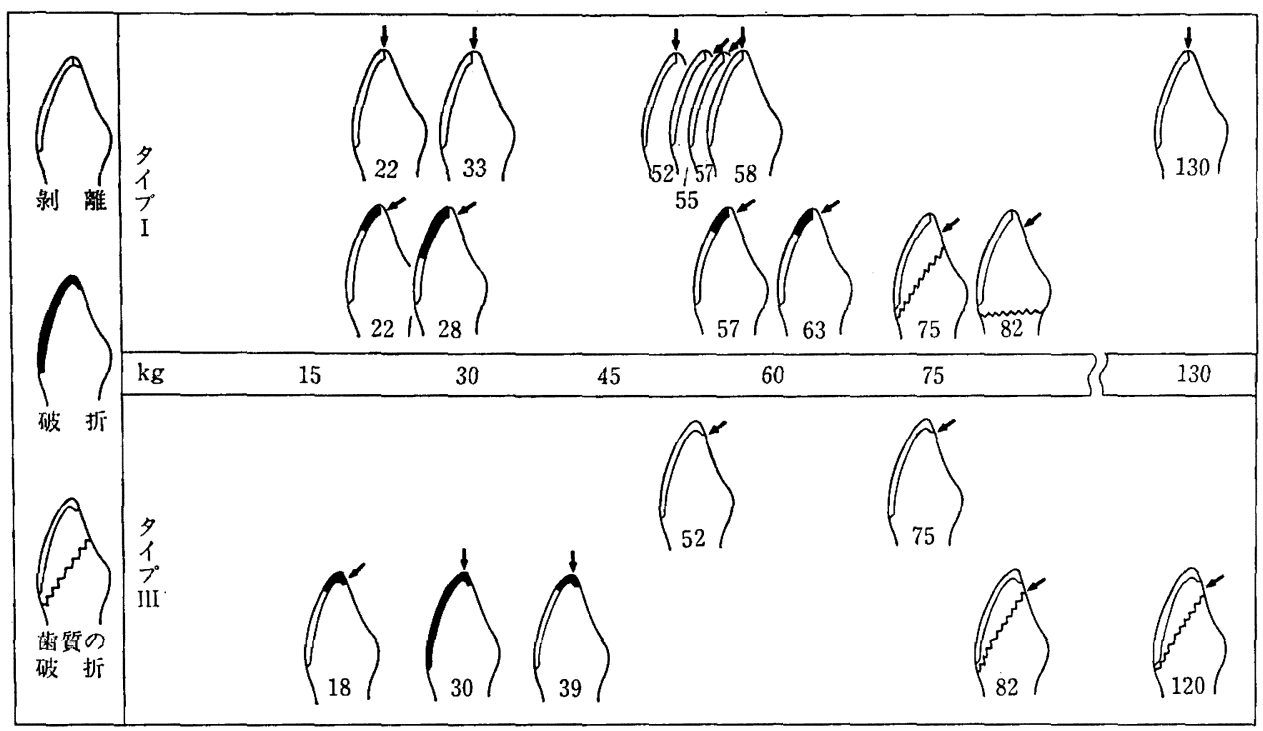

Fig. 12 ポーセレンベニアクラウンの破折テスト結果

$75 \mathrm{~kg})$, ベニアクラウンの破折が 3 ケース (18, 30,39 $\mathrm{kg})$ ，歯質の破折が 2 ケース $(82,120 \mathrm{~kg})$ であった.

\section{IV. 考察}

ポーセレンラミネートベニアクラウンは, 審美性に優 れている上に臨床術式も簡便といわれているが，支台歯 の形態やポーセレンの破折, 剝離の可能性が臨床上の問 題となるところである.

ポーセレンの引張強度を $3.03 \mathrm{~kg} / \mathrm{mm}^{2}$ と考えるなら ば, Fig. 6 の結果をみると平均的被蓋位置 (C), 舌面中 央 (D), 基底結節部 (E) に荷重をかけた場合, 支台歯の 形態にかかわらずラミネートベニアクラウンに生じる最 大引張り応力は約 $0.65 \mathrm{~kg} / \mathrm{mm}^{2}$ と影響はあまりないと 考えられる. また, 荷重 A, B の切端と正常被蓋位置荷 重については, Type I (支台歯の切縁形成が切端まで), Type II (切縁を $0.5 \mathrm{~mm}$ 削除し, 修復物が舌側 $0.5 \mathrm{~mm}$ まで被覆する場合) では，A 荷重では $1.6 \mathrm{~kg} / \mathrm{mm}^{2}$ の 引張り応力が切端部に, B 荷重で $0.65 \mathrm{~kg} / \mathrm{mm}^{2}$ の引張り 応力が切端部より約 $1.0 \mathrm{~mm}$ 歯顠部側に生じ,さらに Type III (修復物が舌側 $1.0 \mathrm{~mm}$ まで被覆する場合) で は, A 荷重では切端部に $2.09 \mathrm{~kg} / \mathrm{mm}^{2}, \mathrm{~B}$ 荷重でも切端 部より約 $1.0 \mathrm{~mm}$ 歯䫫部側に $1.16 \mathrm{~kg} / \mathrm{mm}^{2}$ が生じてい る. このことは, 通常の咬合圧程度では支台歯のどのタ イプにおいてもポーセレンベニア部の破折という直接の 危険性はないが, Type III の支台歯形態に扔いては切端
咬合の場合に破折の危険性を含んでいることを示唆して いる.

次にラミネートベニア部の剝離について考えると, 術 式の不備による剝離は別問題として, 支台歯の形態とべ ニア部の剝離を生じさせるレジンセメント層内に発生す る剪断応力の関係では（Fig. 7, 8) C, D, E 荷重では Type I IIII ともに切端より $1.5 \mathrm{~mm}$ 歯頸部側に 0.3 $\mathrm{kg} / \mathrm{mm}^{2}, \mathrm{~A}, \mathrm{~B}$ 荷重 (切端方向) では, Type I では切端 部分に最高 $0.48 \mathrm{~kg} / \mathrm{mm}^{2}$ であるが, Type II ではA荷 重の時切端部分に $2.25 \mathrm{~kg} / \mathrm{mm}^{2}$, Type III では B 荷重 時切端部分に $1.04 \mathrm{~kg} / \mathrm{mm}^{2}$ と剪断応力は大きくなる. しかし、レジンの剪断応力を $4.89 \sim 8.06 \mathrm{~kg} / \mathrm{mm}^{32)}$ と するならば, Type I〜 IIIの支台歯形態において設定し たすべての荷重 $\mathrm{A} \sim \mathrm{E}$ に対してレジンセメント層の剥離 は少ないと思われる.

ベニアクラウンを支台歯に接着する際の不手際の 1 つ としてレジンセメント層内に気泡を埋入することがあ り, 気泡の大きさ, 位置によって, 㰌美性の劣化に加え てレジンセメント層内の剪断応力が変化することが考え られる.このことがベニアクラウンの剥離の危険性につ ながるかどうかを検討するために，レジンセメント層内 に種々の気泡を設定し Type I 支台歯形態に正常被蓋位 置に $15 \mathrm{~kg}$ 相当の荷重を加えた場合の解析を行った結果 (Fig. 11), 分散気泡では $10 \%$ 内で気泡なしとの差は なく，15\%にになと約 $20 \%$ 応力が増加する. 集中気泡 では, 切端部以外では気泡率よりも気泡の部位により剪 
$154-1108$

断忘力は変化し, 歯頸部では 15\% 以内の分散気泡より も $5,10 \%$ の集中気泡の方が剪断応力への影響は大きい と考えられる. なお, 有気泡時の最大剪断応力は 0.359 $\mathrm{kg} / \mathrm{mm}^{2}$ でありレジンの剪断応力 $4.89 \sim 8.06 \mathrm{~kg} / \mathrm{mm}^{2}$ に比較すると，15\% までの分散気泡および $10 \%$ までの 集中気泡の存在はレジンの剝離に対しては致命的な要因 とはならない, と思われる。

しかし, 今回は荷重位置が正常被蓋の場合の結果であ るため, もしマージン部に集中気泡を設定し切端付近の 荷重を加えた場合は, 剪断応力がさらに大きくなること が予想され，マージン部からのベニアクラウンの剝離の 危険性も考えられる.

模型実験では (Fig. 12), Type I 13 ケースのうちポ 一七レンベニアの剥離が 7 ケース, ポーセレンベニアの 破折が 4 ケース，歯質の破折が 2 ケースであった.

このうち，ポーセレンベニアの剝離は $22 \sim 130 \mathrm{~kg}$ で 起こり, 破折は $22 \sim 63 \mathrm{~kg}$, 歯質の破折は $75,82 \mathrm{~kg}$ で あった.

Type III では， 7 ケース中ポーセレンベニアの剝離は 2 ケース $(52,75 \mathrm{~kg})$, 破折は 3 ケース $(18,30,39 \mathrm{~kg})$, 歯質の破折は 2 ケース $(82,120 \mathrm{~kg})$ であった.

このような模型実験では, 条件の設定が難しく支台歯 形状，大きさ，その新鮮さ程度，また支台歯形成の差等 数多くの要因を含んでいるが, 前歯部最大咬合力といわ れる $15 \mathrm{~kg}$ 以下では剝離, 破折は起こらず, $75 \mathrm{~kg}$ 以上 の高荷重時には歯質自身の破折が生じるケースもみら れ，ポーセレンベニアは臨床に使用するには十分な強度 をもつと考えられる.

\section{V. 結 論}

ポーセレンラミネートベニア法を施した上顎中切歯に 咬合力が加わった場合を想定して, 二次元有限要素法的 解析と模型実験を行った結果, 以下の知見が得られた.

1. ポーセレンベニア部への影響

荷重位置が切端方向の場合, 支台歯形態による差が見 られ，ベニアクラウンが舌側まで被覆した場合が最も応 力値が高い.

また, 荷重方向から考えると切端方向からの荷重の場 合が最も応力値が高い.

2.レジンセメント層への影響

荷重位置が切端方向の場合は, 切端付近に支台歯の形 態による影響が認められ, 最先端部 (切端) では, ベニ アクラウンが舌側をで被覆した場合が最も応力值が高
32 巻 5 号 (1988)

W.

\section{3. 気泡による影響}

分散気泡よりも，集中気泡による剪断応力への影響が 大きい. また集中気泡の場合，気泡率よりも気泡の部位 により大きく左右される.

\section{4. 模型実験}

$15 \mathrm{~kg}$ 以内ではポーセレンベニアの剥離，破折はみら れず, $75 \mathrm{~kg}$ 以上の高荷重時には歯質自身の破折がみら れた.

以上により，正常被蓋位置からの荷重に対してはべニ アクラウンはカ学的に十分臨床に耐え得るものである が，支台歯を舌側まで形成した時やマージン部分に集中 気泡が存在した時に切端から咬合力が加わった場合に は, ベニアクラウンの剝離, 破折の危険性が考えられ る.

稿を終るに臨み，本研究に想切なるご指導を賜りました九州 大学応用力学研究所, 高雄善裕助教授に感謝の意をささげます. また種々，ご協力いただきました匛用力学研究所の所員各氏に 深謝いたします.

本論文の要旨は, 昭和 62 年 5 月, 第 77 回日本補緅歯科学会 学術大会において発表した.

\section{文献}

1) Weiner, S. : Staining Porcelain veneer restorations, J Prosthet Dent, 44 (6) : 670 672, 1980.

2) Chiche, G.J., Mikhall, MG. : Atraumatic removal of porcelain veneer crowns after interim cementation, J Prosthet Dent, 53 (2) : 164 165, 1985.

3) Mclean, JW. : Surface characterization of the porcelain veneer crown (II), Quintessence Int, 10 (11) : 27 32, 1979.

4) Mclean, JW. : Surface Characterization of the porcelain veneer crown (I), Quintessence Int, $10(10): 65 \sim 69$, 1979.

5) Ibsen, RL. and Strassler, H.E. : An innovative method for fixed anterior tooth replacement utilizing porcelain veneers, Quintessence Int, 19 (8) : 455 459, 1986.

6) Calamia, JR. : Etched porcelain veneers : The current state of the art, Quintessence Int, 16 (1):5 12, 1985.

7) Braze, GW. : Cosmetic Laminate dentistry $\cdots \cdots$...for better or for worse. Part II. $\cdots$...the porcelain laminates; Trends Tech Contemp Dent Lab, 3 (2) : 20 23, 1986.

8) Christensen, GJ. : Veneering of teeth. State of the art., Dent Clin North Am, 29 (2) : 373 391, 1985. 
9) Minato, KS. : Esthetic porcelain veneers, Part II, Hawaii Dent J, 17 (8) : 12 14, 1986.

10) Minato, KS. : Esthetic porcelain veneers, Part I, Hawaii Dent J, 17 (7) : 12, 15, 21, 1986.

11) Boksman, L., Jordan, RE., Suzuki, M., Galil. K.A., and Burgoyne, AR. : Etched porcelain labial veneers, Ont Dent, 62 (1) : 11, 13, 15 19, 1985.

12) Czarkowski, MA. : Porcelain-laminate veneer and duralingual bridge studied and evaluated, $78(2): 23 \sim 29$, 1985.

13) Quinn, F., Mcconnell, R.J. and Byrne, D. : Porcelain laminates, a review, Br Dent J, 161 (2) : 61 65, 1986.

14）今井 誠: 光重合型接着性レジンとポーセレンラミネート ベニアによる変色歯の修復について, 補緅誌, 31 (1):224, 1987.

15）保母須弥也, 岩田健男: 鋳造用アパタイト質セラミックス によるベニア修復法, the Quintessense, 14 (3)：103 120, 1985.

16）岩田健男 : ポーセレン・ラミネートベニア法の臨床, the Quintessense, 5 (8) : 39 54, 1986.

17）田村勝美, 岡部弘昭 : ポーセレンラミネートベニアテクニ ックの技工術式, 歯科技工, $14(8): 949 \sim 956,1986$.

18）中川孝男, 田村勝美 : ポーセレンラミネートテクニックの 概要とその接着操作, 歯科技工, 14 (8): 963 973, 1986.

19）田村勝美, 岡部弘昭 : ポーセレンラミネートテクニックに おける技工の要点, 歯科技工, $14(8): 975 \sim 983,1986$.

20）中川孝男, 田村勝美 : ポーセレンラミネートテクニックに よる審美修復，歯科技工，14(8)：984 988，1986.

21）田村勝美 : ポーセレンラミネーションテクニックの臨床,
歯科技工, $13(10): 1244 \sim 1252,1985$.

22) Simmonsen, R.J. and Calamia, JR. : Tensile bond strength of etched porcelain, J Dent Res (Abstruct), 1154, March, 1983.

23) Buonocor, M.G. : A simple method increasing the adhesion of acrylic filling materials to enamel surface, $J$ Dent Res, 34 : 849, 1955.

24) Bowen, R.L. : Adhesive bonding of varions materials to hard tooth tissues I V, J Dent Res, $44: 690$ (I), 895 (II), 903 (II), 906 (IV), 1369 (V), 1961.

25) Silverstone, L.M.S, axton, C.A., Dogon, I.L. and Fejerskov, O. : Variations in the pattern of acid etching of human dental enamel examined by scanning electron microscopy, Caries Res, $9: 373,1975$.

26) Harry, F. and Albers, D.D.S. : Tooth colored restorations, A Text for Selection, Placement and Finishing, Seventh Edition.

27）浅埜 曻: 上顎中切歯の測径成績に就て, 䠦床 歯科, 2 : 1930.

28）有田正俊：切歯幅に関する統計学的研究，歯科学雄誌，8: 1952.

29）吉永喜久雄：上䫑中切歯の臨床的研究，口腔科学，4： 1941.

30）藤田恒太郎 : 日本人の永久歯の大きさについて. 解剖学雑 誌, $24: 1949$.

31）藤田恒太郎：歯の計測規準について, 人類学雑誌, 61 : 1949.

32) Craig, R.G., Pexton, F.A. : Restorative dental materials, fifth edition, 435, 1975. 